Pakistan Journal of Humanities and Social Sciences
Volume 8, Number 1, 2020, Pages $23-27$

\title{
Role of Political Participation in Women's Empowerment at Charsadda, Khyber Pakhtunkhwa
}

\author{
Muhammad Hussain ${ }^{1}$, Azizullah Jan², Ihsan Ullah Khan ${ }^{3}$, Abid $\mathrm{Ali}^{4}$ \\ ${ }^{1}$ M.Phil Scholar, Department of Sociology, University of Peshawar \\ 2Department of Sociology University of Peshawar, Email: azizj153@gmail.com \\ ${ }^{3}$ Department of Sociology University of Peshawar, Email: ihsansoc@uop.edu.pk \\ ${ }^{4}$ Lecturer in Sociology Hazara University, Mansehra Khyber Pakhtunkhwa, Email: abidalisocio472@gmail.com
}

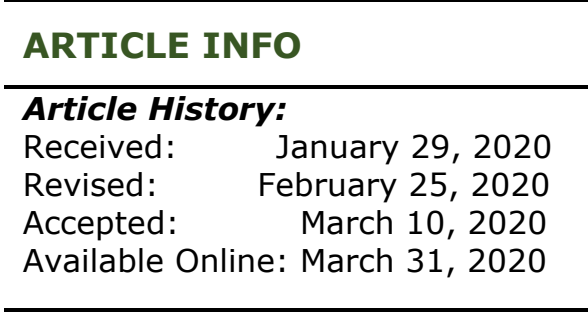

\section{Keywords:}

Women Participation in Politics Women Empowerment

Awareness

\section{JEL Classification Codes:}

F50, D83, N15

\section{ABSTRACT}

Political participation one of the important factors of empowerment and creates awareness among females about their rights in society. The current study was carried out on "The role of political participation in women's empowerment at Charsadda, Khyber Pakhtunkhwa". The sample size for the data collection was 200 respondents. Data were collected from 200 respondents while applying the criteria designed by Sekaran, aging of the respondents (15-49) who were belonging to two union councils: Behlola and Mohammad Nari of district Charsadda through simple random sampling technique. The interview schedule was used for the data collection. Structured and semi-structured questions were included in the interview schedule. After collection, the data were processed through SPSS and tabulated as well as presented in percentages and frequencies for better understanding. A Chi-square test was used for measuring the association between the independent variable and dependent variables. The study findings suggested that change in female formal literacy can transfer about better awareness and self-confidence. The study also recommends the significant involvement of government and non-government agencies for activating women clusters, as well as increasing women awareness level, political participation awareness, and learning skills. The study findings suggested that a woman leader can better empower women in the future, as well as a female candidate can better solve their problems as compared to male.

(c) 2020 The Authors, Published by iRASD. This is an Open Access Article under the Creative Common Attribution Non-Commercial 4.0

Corresponding Author's Email: abidalisocio472@gmail.com

\section{Introduction}

Political participation supposedly is one of the important factors of empowerment which creates awareness and consciousness among women about their rights in society. It ensures power and strength to women to choose those leaders who have the ability of know-how about women related issues and reduce gender disparity. Moreover, it offers a chance for women to select those leaders who know how to solve their local problems and to eliminate the gender gap (Mahmood,2010). But in Pakistani society and especially rural areas in Pakhtun society, women are restricted mostly and have no access to political participation and empowerment services (Naz, 2012). The political participation of women and women's empowerment are interconnected with each other. Through, the political participation of women can easily encourage women to address their issues and solve them according to their wishes and desire (Mahmood, 2010). The participation of women in politics is lower than males, but the Pakistani women's position in politics is encouraging as compared to other countries. The participation of women of Pakistan in politics is on the $50^{\text {th }}$ position in the world ranking order (Hausmann et al.,2009). 
According to Stromquist (1995) political participation is a prerequisite for women empowerment as through political support upgrade limit working among women to oversee, break down, and activate assets for social change. Another study which is conducted by Oxaal and Baden (1997) views that on their adjacent problems. Batliwala (1995) views that democracy plays a significant role in raising political awareness among the masses. Without democratic political systems, the process of empowerment is incomplete. Chandra (1997) favors the political participation of women at a grass root level which can help upgrade females' position and empower them. Moreover, to provide and develop a good political culture for women, endeavors ought to be made to increment political awareness among women at the nearby level that can bring a weight gathering of women for taking care of their related issues at the neighborhood level and showing their significant issues at a larger amount.

Similarly, Hust (2002) has inferred that the greatest number of women taking an interest in political improvement helps each other to challenge the current power structure, talk about sexual orientation connection issues, and additionally strengthens them to advance an enabling situation. Furthermore, McKenna (1999) views that political cooperation underpins women to build up a political culture that helps women cause and fuses more women in the essential leadership handle, as showed by Bari (2005) that political investment is enthusiastic not just to develop individual and aggregate movement but also is significant for making opportunities that lead women toward empowerment. Pini (2002) avows that five key components control women's contribution to agro-governmental issues. It comprises of time and area of gatherings, the absence of support, the conduct, gender-biased culture of association, women's absence of intrigue.

The study aimed to highlight the problems faced by women while participating in the political activities in district Charsada of Khyber Pakhtunkhwa. The study also tries to investigate that either their participation in political activities reduced their problem. The study further revealed that women's participation in political activities leads to their empowerment in day to day life.

\section{The Methodology of the Study}

This study is quantitative and based on both primary and secondary data. The primary data was collected through the interview schedule while secondary data was taken from the existing literature on the subject issue. This study is carried out in two union councils (Behlola and Mohammad Nari) of Charsadda district. Married and unmarried women between the age (15-49) constitute the universe of the study. Though a sample of 200 female respondents was, selected for this study. The respondents were interviewed by a self-structured semi-interview through a simple random sampling technique. Structured and semi-structured questions were included in the interview schedule. The chi-square test was applied to find out the relationship between the dependent and independent variables.

\section{Results and Discussion}

This section of the study consists of three parts. The first part is about the demographic information while the second part showed the Uni-variate relation of the findings and last but not least showed the $\mathrm{Bi}$-variate association between dependent and independent variables. The above showed demographic information of the respondents in which $10 . \%$ of the respondents were the age between $16-20,12.5 \%$ were of the age $21-25,19 \%$ were of the age $26-30$ and $13 \%$ of the respondents were betweentheage36-40. Further, the majority of the respondents $24 \%$ were illiterate, $21 \%$ primary level of education, $11 \%$ were matric level and only $2 \%$ were master-level education. Proceeding to marital status and family type in which $66 \%$ were married and $24 \%$ were unmarried respondents. While $44 \%$ of the respondents in the study area belonged to the nuclear family, $53 \%$ related to a joint family system and only $3 \%$ of the respondents were living in an extended family system.

At the occupational level, $6.5 \%$ of the respondents connected with a Government job, $7.5 \%$ of the respondents belonged to private occupation and $72 \%$ were housewives. While in monthly income, $61 \%$ have no monthly income (jobless), $21.5 \%$ of the respondents have a monthly income between Rs1001-10000, $1 \%$ of the respondents had a monthly income between Rs20001-30000 and only $1 \%$ of the respondents had monthly income above than Rs30000. 
Table 1: Demographic Information of the Respondents

\begin{tabular}{|c|c|c|c|}
\hline Attributes & Items & Frequency & Percentage \\
\hline \multirow{7}{*}{ Age of Respondent } & $16-20$ & 20 & 10 \\
\hline & $21-25$ & 25 & 12.5 \\
\hline & $26-30$ & 38 & 19 \\
\hline & $31-35$ & 36 & 18 \\
\hline & $36-40$ & 26 & 13 \\
\hline & $41-45$ & 37 & 18 \\
\hline & Above 45 & 18 & 8 \\
\hline \multirow{6}{*}{ Educational Level } & Illiterate & 48 & 24 \\
\hline & Primary & 42 & 21 \\
\hline & Matric & 22 & 11 \\
\hline & Intermediate & 8 & 4 \\
\hline & Graduate & 9 & 4.5 \\
\hline & Master & 4 & 2.0 \\
\hline \multirow{4}{*}{ Marital Status } & Married & 133 & 66.5 \\
\hline & Unmarried & 48 & 24 \\
\hline & Divorce & 3 & 1.5 \\
\hline & Widow & 16 & 8 \\
\hline \multirow{3}{*}{ Type of Family } & Nuclear family & 88 & 44 \\
\hline & Joint family & 106 & 53 \\
\hline & Extended family & 6 & 3 \\
\hline \multirow{5}{*}{ Respondent Occupation } & Government & 13 & 6.5 \\
\hline & Private & 15 & 7.5 \\
\hline & Semi-Government & 20 & 10.5 \\
\hline & Housewife & 144 & 72 \\
\hline & Others & 8 & 4 \\
\hline \multirow{6}{*}{ Income Level } & No income & 122 & 61 \\
\hline & 1 up to 1000 & 25 & 12.5 \\
\hline & 1001 up to 10000 & 43 & 21.5 \\
\hline & 10001 up to 20000 & 6 & 3 \\
\hline & 20001 up to 30000 & 2 & 1 \\
\hline & Above 30000 & 2 & 1 \\
\hline
\end{tabular}

Table 2: Univariate Analysis of Political Participation and Women Empowerment

\begin{tabular}{|c|c|c|c|c|}
\hline Statements & Agree & Disagree & Don't Know & Total \\
\hline $\begin{array}{l}\text { You cast your vote for the propose of } \\
\text { empowerment }\end{array}$ & $38(19)$ & $151(75.5)$ & $11(5.5)$ & $200(100)$ \\
\hline You cast your vote by your own choice & $24(12)$ & $144(72)$ & $32(16)$ & $200(100)$ \\
\hline $\begin{array}{l}\text { You cast your vote as dictated by } \\
\text { husband/ father or brother's choice }\end{array}$ & $120(60)$ & $66(33)$ & $14(7)$ & $200(100)$ \\
\hline $\begin{array}{l}\text { A woman leader can better empower } \\
\text { women in the future }\end{array}$ & $173(86)$ & $13(6.5)$ & $14(7)$ & $200(100)$ \\
\hline $\begin{array}{l}\text { A female can do ate can solve your } \\
\text { problem bitterly as compared to a male }\end{array}$ & $181(90.5)$ & $17(8.5)$ & $2(1)$ & $200(100)$ \\
\hline $\begin{array}{l}\text { Women should personally participate in } \\
\text { elections }\end{array}$ & $20(10)$ & $161(80.5)$ & $19(9.5)$ & $200(100)$ \\
\hline
\end{tabular}

Table values in each cell indicate frequency while the value of parenthesis indicated percentage. Table showing the response categories in which $38(19 \%)$ of the respondents viewed that they cast their vote for the propose of empowerment while151 $(75.5 \%)$ disagreed with the statement. Further, $24(12 \%)$ of the respondents thought that they cast their votes by their own choice. While majority $144(72 \%)$ of the respondents disagreed with the statement and expressed that they cannot cast vote my own choice but due to some cultural and social pressures. In cultural context 120 (55\%) of the respondents viewed that women cast their vote as dictated by husband/father or brother's choice. While $66(33 \%)$ disagreed. A maximum number of the respondents $173(86 \%)$ preferred that a women leader can better empower women in the future whereas, 13(6.5) disagreed with the statement. Most of the respondents $181(90.5 \%)$ agreed that female candidates can better solve your problem as compared to a male candidate. While $17(8.5 \%)$ disagreed with the statement and only $2(1 \%)$ did not answer 25 
the statement. About $20(10 \%)$ viewed that women should personally participate in elections. While the majority of respondents disagreed 161 (80.5) with this statement and $19(9.5 \%)$ did not answer the statement which was shown as the "don't know" option in the table below.

\begin{tabular}{|c|c|c|c|c|c|c|}
\hline Statement & Response & Agree & Disagree & Don't know & Total & Square \\
\hline $\begin{array}{l}\text { Women cast their } \\
\text { vote for the } \\
\text { propose of } \\
\text { empowerment }\end{array}$ & $\begin{array}{c}\text { Agree } \\
\text { Disagree } \\
\text { Don't know } \\
\text { Total }\end{array}$ & $\begin{array}{c}19(9.5) \\
99(48.5) \\
3(1.5) \\
121(60.5)\end{array}$ & $\begin{array}{c}18(9) \\
50(25) \\
7(3.5) \\
75(37.5)\end{array}$ & $\begin{array}{c}1(0.5) \\
2(1) \\
1(1) \\
4(2) \\
\end{array}$ & $\begin{array}{c}38(19.0) \\
151(70.5) \\
11(5.5) \\
200(100) \\
\end{array}$ & $\begin{array}{l}291 \\
36)\end{array}$ \\
\hline $\begin{array}{l}\text { Women's } \\
\text { vote by }\end{array}$ & $\begin{array}{c}\text { Agree } \\
\text { Disagree } \\
\text { Don't know } \\
\text { Total }\end{array}$ & $\begin{array}{c}19(9.5) \\
79(39.5) \\
23(11.5) \\
121(60.5)\end{array}$ & $\begin{array}{c}3(1.5) \\
63(31.5) \\
94.5) \\
75(37.5)\end{array}$ & $\begin{array}{l}2(1) \\
2(1) \\
0 \\
4(2)\end{array}$ & & \\
\hline $\begin{array}{l}\text { Women's cast their } \\
\text { vote as dictated by } \\
\text { husband/ father or } \\
\text { brother choice }\end{array}$ & $\begin{array}{c}\text { Agree } \\
\text { Disagree } \\
\text { Don't know } \\
\text { Total } \\
\end{array}$ & $\begin{array}{r}80 \\
31( \\
10 \\
121 \\
\end{array}$ & $\begin{array}{r}39(1 \\
32( \\
4( \\
75(3\end{array}$ & $\begin{array}{c}0 \\
4(2) \\
\end{array}$ & $\begin{array}{r}120 \\
66 \\
14 \\
(200 \\
\end{array}$ & \\
\hline $\begin{array}{l}\text { A better women } \\
\text { leader can } \\
\text { empower women }\end{array}$ & $\begin{array}{c}\text { Agree } \\
\text { Disagree } \\
\text { Don't know } \\
\text { Total }\end{array}$ & $\begin{array}{r}103 \\
11 \\
7( \\
121\end{array}$ & $\begin{array}{r}681 \\
2( \\
5(2 \\
75(3\end{array}$ & $\begin{array}{l}2(1) \\
0 \\
2(1) \\
4(2)\end{array}$ & $\begin{array}{r}173( \\
13( \\
14 \\
(200\end{array}$ & \\
\hline $\begin{array}{l}\text { A female candidate } \\
\text { can better resolve } \\
\text { your problem as } \\
\text { compared to a } \\
\text { male candidate }\end{array}$ & $\begin{array}{c}\text { Agree } \\
\text { Disagree } \\
\text { Don't know } \\
\text { Total }\end{array}$ & $\begin{array}{r}108 \\
12 \\
1(0 \\
121(\end{array}$ & $\begin{array}{c}70(35) \\
4(2) \\
1(0.5) \\
75(37.5)\end{array}$ & $\begin{array}{c}3(1.5) \\
1(0.5) \\
0\end{array}$ & $\begin{array}{c}181(90.5) \\
17(8.5) \\
2(1)\end{array}$ & $\begin{array}{l}5 \\
1)\end{array}$ \\
\hline $\begin{array}{l}\text { Women personally } \\
\text { participate in } \\
\text { elections }\end{array}$ & $\begin{array}{c}\text { Agree } \\
\text { Disagree } \\
\text { Don't know } \\
\text { Total } \\
\end{array}$ & $\begin{array}{c}12(6.0 \\
98(49.0) \\
11(5.5) \\
121(60.5)\end{array}$ & $\begin{array}{c}8(4.0) \\
60(30.0) \\
7(3.5) \\
75(37.5) \\
\end{array}$ & $\begin{array}{c}0 \\
3(1.5) \\
1(.5) \\
4(2.0) \\
\end{array}$ & $\begin{array}{c}20(10.0) \\
161(80.5) \\
9(4.5) \\
(200(100)\end{array}$ & $\begin{array}{c}x^{2}=1.490 \\
(p=0.828)\end{array}$ \\
\hline
\end{tabular}

Table values in each cell indicate frequency while the value of parenthesis indicated percentage. Based on findings in the table highlighted that the significant association $(P=.036)$ existed between the independent variable women cast their vote for the propose of empowerment with the dependent variable women empowerment. The data explored significant association ( $P=.005)$ was found between the statements women's cast their vote by their own choice with women empowerment. This statement fully negates the opinion of Naz, (2012) that in our country Pakistan women in rural have restricted to cast their vote for the resolution of their problems. Furthermore, the information regarding independent variable women's cast their vote as dictated by husband/father or brother choice with dependent variable women empowerment was found a significant association $(P=.050)$. The table further explores a strong significant association $(P=.005)$ that exists between a better women leader can empower women in the future with women empowerment. The said finding favored the idea of Chandra (1997) that awareness in women regarding their empowerment is slightly created due to participation in politics. On the contrary, a non-significant association $(P=.591)$ found between the statements a female candidate can better resolve your problem as compared to a male candidate with women empowerment. Similarly, the result revealed a non- significant association $(P=(.828)$ was found between the independent variable statement women personally participate in elections with the dependent variable statement women empowerment. This finding of the study fully supports the statement of Hust (2002), that if women participate in active politics can leads towards the hurdle in their day to day life.

\section{Conclusion}

Based on quantitative analysis and information provided, there are significant results to realize the phenomenon of political participation and women's empowerment. The study also explored that women do not cast their vote for their own choice, but mostly cast their vote dictated by their husband/ father or brother's choice. The study has also investigated that a women leader can better empower women. Furthermore, a female leader can better resolve 
women related issues as compared to male candidates. It concludes that women have a low perception of how to cast their votes for women's empowerment. This is further concluded that the political participation of women and women's empowerment are interconnected with each other. Through the political participation of women, it can easily encourage and award women to address their issues and solve them according to their wishes and desire.

\section{References}

Bari, F. (2005, November). Women's political participation: Issues and Challenges. In United Nations Division for the Advancement of Women Expert Group Meeting: Enhancing Participation of Women in Development through an Enabling Environment for Achieving Gender Equality and the Advancement of Women. Bangkok, P 393.

Batliwala,S.(1995,September).Defining women's empowerment: A conceptual framework. In Education for Women's Empowerment. Position Paper for the Fourth World Conference on Women, Beijing. New Delhi: ASPBAE, Pp 54-57.

Chandra, S. K. 1997. Women and empowerment. Indian Journal of Public Administration, 43 (4): Pp 395-99.

Hausmann, R., Zahidi, S., Tyson, L., Hausmann, R., Schwab, K., \& Tyson, L. D. A. (2009). The global gender gap report. World Economic Forum, P121

Hust, E. (2002). Political Representation and Empowerment: Women in the Institutions of Local Government in Orissa after the 73rd Amendment to the Indian Constitution,45

Mahmood, T. (2010). Socio-Cultural Determinants of Women's. Ph.D. Thesis, Dept Rural Sociology, Univ. Agri. Faisalabad, Pp 31-36.

McKenna, M. R. 1999. Strengthening democracy through women's participation: A seminar on emerging issues in Asia (panel II). April 14, 1999. The Asia Foundation Washington, D. C. USA.

Naz, A., \& Ahmad, W. (2012). Socio-cultural impediments to women political empowerment in Pakhtun society. Academic Research International, 3(1), 163-164.

Oxaal, Z., \& Baden, S. (1997). Gender and Empowerment: Definitions. Approaches and Implications for Policy, BRIDGE Report, (40). Bridge, Institute of Development Studies, University of Sussex, UK, Pp78-82.

Phillips, A. (1995). The politics of presence. Clarendon Press. P 234.

Pini, B. (2002). Constraints to women's involvement in agricultural leadership. Women in Management Review, 17(6), 276-284.

Stromquist, N. P. (1995). Romancing the state: Gender and power in education. Comparative education review, 39(4), 423-454. 